\title{
The Front Runner Patricii Nell Warren. Coming out, czyli zwycięstwo i koniec tragediii ${ }^{1}$
}

https://doi.org/10.51897/interalia/UKEA5086

\author{
Mateusz Świetlicki \\ Uniwersytet Wrocławski \\ ORCID: 0000-0001-7009-3837
}

W niniejszym artykule chciatbym przybliżyć czytelnikom nieznana w naszym regionie anglojęzyczna twórczość Patricii Nell Warren na przykładzie jej najbardziej znanego utworu The Front Runner (1974), powieści, w której autorka porusza kwestie homofobii i mizoginii w sporcie, jak również różne doświadczenia ujawniania homoseksualnej orientacji dwóch pokoleń mężczyzn. Biorąc pod uwagę koncepcję potrójnej mimesis Paula Ricoeura, skupię się na relacji między własnym doświadczeniem autorki a narracyjna problematyka powieści, jak również wieloznaczna recepcja utworu wśród przedstawicieli spoteczności LGBTQ+. Pragnę pokazać, że w kontekście amerykańskim The Front Runner może petnić rolę tekstu kultury i medium pamięci, a dla nowych europejskich czytelników stanowić potencjalne źródło pamięci protetycznej, dostarczające literacką reprezentację doświadczenia ujawnienia orientacji homoseksualnej i zmieniających się postaw społecznych wobec niebinarnych ról ptciowych i nieheteroseksualności zaraz po zamieszkach w Stonewall i przed epidemia AIDS. Pragnę też zauważyć, że zapoznanie polskich czytelników z prozq Warren może stać się impulsem do queerowej reinterpretacji wcześniejszej poezji autorki Tragedii pszczół.

Stowa klucze: homofobia, mizoginia, heteronormatywność, literatura gejowska, literatura amerykańska, mimesis, pamięć

Before coming out of the closet and publishing a series of successful gay novels, Patricia Nell Warren was known as Patricia Kilina, wife of a Ukrainian émigré writer George Tarnawsky. Her early poetry, written in Ukrainian, includes numerous references to non-traditional gender roles which she further explored in her anglophone novels. The Front Runner (1974) was published when Warren had already divorced her husband and came out of the closet. It was met with commercial success and became the first contemporary American bestseller about gay love. In this paper, I focus on the mixed reader-response of The Front Runner in the LGBTQ+ community, as well as the role of homophobia and misogyny in Patricia Nell Warren's novel. I argue that The Front Runner provides readers with a thought-provoking literary representation of the changing social attitudes towards nonbinary gender roles and non-heterosexuality right after Stonewall and before the AIDS epidemic.

Keywords: homophobia, misogyny, heteronormativity, gay literature, American literature, mimesis, memory

Teraz szukam tragedii

Ponieważ jedna dobra tragedia Jest warta tysiąca chimer

(Warren 2014, 321)

\footnotetext{
${ }^{1}$ Niektóre tezy oraz fragmenty niniejszego tekstu zostały włączone do mojego artykułu pt. Змагання за ідентичність $i$ суперечки про досвід. „The Front Runner« Патрицї̈ Нелл Воррен оpublikowanego kilka miesięcy przed śmiercią Warren w piśmie „Літературознавчі обрії. Праці молодих учених" 25, 2018, s. 75-82.
} 
W niniejszym artykule chciałbym przybliżyć czytelnikom nieznaną w naszym regionie anglojęzyczną twórczość Patricii Nell Warren na przykładzie jej najbardziej popularnego utworu The Front Runner (1974), powieści, w której autorka porusza kwestie homofobii i mizoginii w sporcie, jak również różne doświadczenia coming outu dwóch pokoleń mężczyzn. Choć problematyka ta jest odległa historycznie i geograficznie, sądzę, że może być odczytana jako relewantna we współczesnej Polsce, gdzie zarówno kobiety, jak i mniejszości seksualne wciąż mierzą się z dyskryminacją, czego przykładem są stałe próby ograniczania praw kobiet i ciągle rosnąca liczba "stref wolnych od ideologii [sic!] LGBT". Biorąc pod uwagę koncepcję potrójnej mimesis Paula Ricoeura zaprezentowaną w traktacie Czas i opowieść (19831985), która, jak zauważa Astrid Erll, pomaga „zilustrować kompleksowe, wzajemne relacje między literaturą a pamięcią kulturową" (2018: 235), skupię się na relacji między własnym doświadczeniem autorki a narracyjną problematyką powieści, jak również wieloznaczną recepcją utworu wśród przedstawicieli amerykańskiej społeczności LGBTQ+2 ${ }^{2}$ Odwołując się do Arystotelesowskiej koncepcji, Ricoeur wprowadza model koła mimesis, rozróżniając jego trzy poziomy - mimesis I (odwoływanie się tekstu do świata pozatekstualnego), mimesis II (konfigurowanie tekstu, fabularyzacja i kreowanie świata fikcyjnego), i mimesis III (dokonywana przez czytelnika refiguracji tekstu). (2008: 17). Wykorzystanie tej koncepcji pozwoli mi pokazać, że w kontekście amerykańskim The Front Runner może pełnić rolę tekstu kultury i medium pamięci ${ }^{3}$, a dla nowych europejskich czytelników stanowić potencjalne źródło pamięci protetycznej ${ }^{4}$, dostarczające literacką reprezentację doświadczenia ujawnienia orientacji homoseksualnej i zmieniających się postaw społecznych wobec niebinarnych ról płciowych i nieheteroseksualności zaraz po zamieszkach w Stonewall i przed epidemią AIDS. Pragnę też zauważyć, że zapoznanie polskich czytelników z prozą Warren może stać się impulsem do queerowej reinterpretacji wcześniejszej poezji autorki, zawartej w trzech tomach wydanych w latach 60. XX wieku 5 .

\section{Prefiguracja - od emigracyjnej poetki do ikony amerykańskich gejów}

Patricia Nell Warren (1936-2019), pochodząca z Montany dwudziestosześcioletnia pisarka, poślubiła w 1957 roku młodego ukraińskiego poetę emigracyjnego Jurija Tarnawskiego i nauczyła się języka ukraińskiego. Zniechęcona brakiem sukcesów wydawniczych w języku angielskim, trzy lata po ślubie zaczęła publikować pod pseudonimem Patricia Kilina poezję pisaną po ukraińsku. Zabieg ten pozwolił

\footnotetext{
${ }^{2}$ W tekście stosuję termin LGBTQ + na określenie przedstawicieli mniejszości seksualnych, mając na myśli zarówno współczesnych czytelników, jak i krytyków powieści z lat 70. XX wieku. Pragnę jednak zauważyć, że akronim ten jest współczesny i nie istniał w latach 60. i 70. Jednakże ze względu na zachowanie klarowności wywodu, jak również w związku z obecnością w powieści Warren nie tylko gejów, ale również lesbijek i osób transseksualnych, pozwalam sobie na zastosowanie tego inkluzywnego terminu.

3 Używam tego sformułowania w rozumieniu zaproponowanym przez Aleidę Assmann (2018: 23-38). Jak podkreśla Erll, model Ricoeura można wykorzystać do potraktowania literatury jako medium pamięci kulturowej (2018: 235).

${ }^{4}$ Określenie to zaproponowała amerykańska badaczka Alison Landsberg, mówiąc o mnemonicznym potencjale mediów. Autorka stwierdza, że wspomnienia protetyczne są niczym sztuczne kończyny wytworzone poprzez kontakt z reprezentacją medialną (np. w formie filmu, serialu) dotyczącą konkretnego wydarzenia historycznego (Landsberg, 2018: 165-172).

5 Tragedia pszczót (Трагедія джмелів, 1960), Legendy і sny (Леґенди і сни, 1964), Różowe miasta (Рожеві міста, 1969). Jedynym tekstem Warren dostępnym w przekładzie na język polski jest esej „Tragedia pszczół - będąc poetką na wygnaniu". Zawarte są w nim fragmenty kilku wierszy autorki w tłumaczeniu autora niniejszego artykułu - Zob: Warren 2014.
} 
jej przybrać nową, jednak niezależną od męża, tożsamość twórczą. W karierze ukraińskiej „emigracyjnej poetki" amerykańskie pochodzenie Warren umożliwiło jej publikowanie w takich miejscach jak Hiszpania i Związek Radziecki, gdzie, w odróżnieniu od Tarnawskiego, nie była postrzegana jako polityczny wróg ukrywający się za żelazną kurtyną, ale jako Amerykanka, która imponująco szybko nauczyła się trudnego języka słowiańskiego (Warren, 2014: 324). Warto w tym miejscu zauważyć, że ukraińskojęzyczna twórczość autorki tomu Tragedia pszczół okazała się tak przekonująca, że do tej pory w kontekście ukraińskim Kilina bywa traktowana jako amerykańska pisarka ukraińskiego pochodzenia, a jej twórczość odczytywana jest przez pryzmat tęsknoty za krajem. Z kolei w kontekście amerykańskim, ukraińskojęzyczna poezja Kiliny jest zupełnie nieznana, do tej pory nie doczekała się tłumaczenia, a ona sama została zapamiętana jako autorka prozy o tematyce gejowskiej, z kultową powieścią The Front Runner na czele.

Jak stwierdza sama Warren w eseju opublikowanym 40 lat później, bez ukraińskojęzycznej poezji nie byłoby The Front Runner ani dalszych powieści, takich jak Harlan's Race (1994) i Billy's Boy (1997), w których autorka powraca do bohaterów swego najbardziej znanego dzieła, czy The Fancy Dancer (1976), pierwszego amerykańskiego bestsellera o życiu małomiasteczkowego księdza geja (2014: 30). Pisanie w obcym języku, zwłaszcza takim jak ukraiński, którego rozwój był sztucznie hamowany przez politykę carskiej Rosji i ZSRR ${ }^{6}$, pozwoliło Warren stworzyć własny, tajny kod mówienia o odmienności seksualnej i intymności. W przeciwieństwie do pozostałych poetów z awangardowej emigracyjnej Grupy Nowojorskiej zainspirowanej bitnikami, której była członkinią, Kilina nigdy nie przeżyła wojny i trudów migracji, ale będąc ukrytą lesbijką i żoną heteroseksualnego mężczyzny, przez kilkanaście lat prowadziła wewnętrzną walkę o własną tożsamość i samoakceptację. Ukraińskojęzyczna poezja pisana pod pseudonimem stała się dla niej płaszczyzną umożliwiającą wyrażanie tłoczących się w jej głowie pełnych sprzeczności myśli. Ten konflikt wewnętrzny zakończył się, kiedy rozwiodła się z Tarnawskim, w końcu ujawniła się jako lesbijka i w 1974 roku opublikowała The Front Runner pod własnym nazwiskiem, co można odebrać jako symboliczne zaakceptowanie swojej tożsamości ${ }^{7}$ Sama

\footnotetext{
${ }^{6}$ Należy przypomnieć, że rusyfikacja Ukrainy oraz innych państw podległych początkowo rosyjskiemu mocarstwu, a potem ZSRR, sięga jeszcze pierwszej połowy XIX wieku i związana jest z wprowadzoną w 1833 roku przez Siergieja Uwarowa, ministra spraw wewnętrznych Rosji, reformą dotyczącą jedności władzy, języka i religii. Ogłoszony w następstwie utwierdzania reformy Cyrkularz wałujewski z 1863 roku ograniczał w znacznym stopniu wydawanie literatury w języku ukraińskim, pejoratywnie określonym przez Piotra Wałujewa "małoruskim”. Opublikowany przez Aleksandra II w 1876 Ukaz Emski był kontynuacją ostrej polityki rusyfikacyjnej. Zakazano wówczas używania nazwy Ukraina, nauki języka „małoruskiego" oraz publikowania jakichkolwiek tekstów po ukraińsku. Ukaz unieważniony został dopiero w 1907 roku. XX wiek okazał się jeszcze bardziej niszczący dla języka ukraińskiego. W latach 1923-1933 władza sowiecka zastosowała „owocną" ukrainizację, będącą elementem polityki korienizacji. Poprzez propagowanie języka ukraińskiego i likwidację analfabetyzmu dążono do wzmocnienia wpływów radzieckich na Ukrainie. W latach 30. ukrainizację zakończono pod pretekstem walki z ukraińskim „burżuazyjnym nacjonalizmem”. Problem rozwiązany został za pomocą wzmożonej rusyfikacji i kolektywizacji rolnictwa, która przyniosła z sobą Wielki Głód i śmierć wielu milionów Ukraińców, w tym pisarzy i przedstawicieli inteligencji (tzw. Rozstrzelane Odrodzenie). Przymusową rusyfikację, prowadzoną przez ZSRR aż do 1991 roku, częściowo wstrzymano w okresie 1963-1972, podczas destabilizacji. Zastosowanie pozornej ukrainizacji zakończyło się jednak, podobnie jak w latach 20., masowymi aresztowaniami inteligencji ukraińskiej (tzw. Uduszone odrodzenie) (Masenko, 2008).

${ }^{7}$ The Front Runner to druga anglojęzyczna powieść Warren, jednak pierwsza po coming oucie i pierwsza wydana pod prawdziwym nazwiskiem. Trzy lata wcześniej autorka opublikowała The Last Centennial (1971) pod pseudonimem. Chociaż powieść spotkała się z pozytywnym odbiorem krytyków, przeszła bez echa i przez kolejne czterdzieści lat nie była wznawiana. W roku 2012 Warren zdecydowała się udostępnić ją w formie e-booka, tym razem pod własnym nazwiskiem.
} 
Warren podkreśla, nawiązując do tytułu pierwszego zbioru poezji, że coming out "To był koniec tragedii. Tragedie zawsze kończą się pokonaniem i śmiercią. Zdecydowałam, że bardziej interesuje mnie zwycięstwo." (2014: 327).

Swoją przełomową powieścią nie tylko dała wyraz samoakceptacji, ale także przełamała kulturowe tabu. Jako rozwiedziona lesbijka, opowiedziała historię miłości hipermęskich, lecz homoseksualnych sportowców w czasach, gdy bieganie wciąż było uznawane za sport pozwalający utwierdzić stereotypową (heteroseksualną) męskość w czysto homospołecznych warunkach ${ }^{8}$, gdyż kobiety (formalnie) i geje (nieformalnie) byli ze środowiska biegaczy wykluczeni.

\section{Konfiguracja i refiguracja}

Chociaż w 1974 roku, pięć lat po zamieszkach w Stonewall (Valocchi, 2004: 760), amerykańscy geje i lesbijki zdążyli już wywalczyć sobie większą widoczność w dyskursie medialnym, książki o miłości osób nieheteroseksualnych nie były jeszcze częścią amerykańskiego mainstreamu literackiego, a ukazanie się powieści Warren można określić mianem momentu przełomowego w historii popularnej literatury gejowskiej. The Front Runner jako pierwszy współczesny utwór o otwarcie nieheteronormatywnej tematyce pojawił się na liście bestsellerów New York Timesa, sprzedał się w nakładzie ponad dziesięciu milionów egzemplarzy i został przetłumaczony na więcej niż tuzin języków (choć do dziś nie doczekał się przekładu na język polski ani ukraiński). W latach 90. XX wieku ukazały się dwie kontynuacje tej historii. W chwili śmierci Warren pracowała nad kolejną. Powieść opowiada o związku dwóch gejów-sportowców, młodego biegacza Billy'ego Sive'a i jego trenera Harlana Browna. Przygotowując się do Igrzysk Olimpijskich w Montrealu, mierzą się z homofobią powszechną w sporcie i społeczeństwie amerykańskim początku lat 70. Mężczyźni pochodzą z różnych środowisk i pokoleń oraz reprezentują odmienne postawy w stosunku do swojej seksualności.

W retrospektywnym odbiorze powieści przydatna jest wspomniana już koncepcja potrójnej mimesis Ricoeura, reinterpretacji Arystotelesowskiej definicji sformułowanej w Poetyce. Biorąc pod uwagę relacje między autorem, tekstem i czytelnikiem, można zauważyć, że w przypadku powieści Warren doszło do wzajemnego warunkowania między żywym doświadczeniem autorki, czytelników (amerykańskich gejów i lesbijek) i narracyjną formą powieści. Jak zauważa Ricoeur, literatura ma „wywrotowe ostrze, które zwraca [...] przeciwko moralnemu i społecznemu porządkowi [...] Fikcja jest tym, co czyni z języka największe niebezpieczeństwo" (2008: 116).

\footnotetext{
Natomiast pierwszą otwarcie homoseksualną postać Warren wprowadziła w dramacie The Horsemen. Jak pisze autorka: „Zastosowałam tu głęboki symbolizm i zaryzykowałam, kreując swojego pierwszego homoseksualnego bohatera — androgeniczną postać o imieniu Kah-Lee, która popełnia samobójstwo, zeskakując z konia w przepaść, ponieważ nie potrafi wybrać między mężczyznami i kobietami. Kiedy »Nowi Poeci« czytali The Horsemen, mój mąż uszczypliwie spytał mnie o Kah-Lee: »W której ciemnej części twojego umysłu powstał ten potwór?«. Jurij chciał to wiedzieć." (Warren, 2014: 321). Podobieństwo między imieniem bohaterki i pseudonimem Warren nie wydaje się przypadkowe.

${ }^{8}$ Używam tego terminu w rozumieniu zaproponowanym przez Eve Kosofsky Sedgwick: „określenie to stosuje się do »męskich więzi«, które może - tak jak w naszym społeczeństwie - cechować głęboka homofobia, lęk i nienawiść wobec homoseksualistów" (2005: 9).
} 
Jak pisze francuski filozof, mimesis III „oznacza przecięcie świata tekstu i świata słuchacza lub czytelnika" (2008: 106). Znaczenie The Front Runner w kontekście amerykańskim wykracza poza dyskurs literacki, o czym świadczy choćby fakt, że powieść zainspirowała kilku gejowskich sportowców do coming outu i napisania własnych wspomnień dotyczących homofobii w amerykańskim sporcie ${ }^{9}$ (Anderson, 2005: xi). Co więcej, do tej pory ugrupowania gejowskich biegaczy (również poza USA) funkcjonują pod nazwą "The FrontRunners", symbolicznie upamiętniając powieść amerykańskiej autorki (Zeigler, 2002). ${ }^{10}$ Chociaż utwór The Front Runner szybko spotkał się z uznaniem czytelników i wciąż pozostaje ważną książką dla wielu amerykańskich gejów, po jego opublikowaniu Warren musiała zmierzyć się też z potępieniem części społeczności LGBTQ+. Negatywna recepcja książki związana była z określeniem autorki mianem uzurpatorki. To pozycja, z którą Warren nie spotkała się w trakcie swojej ukraińskojęzycznej kariery, choć jako Amerykanka wpisała się przecież w obcy proces historycznoliteracki. Krytyka spowodowana była dysonansem między płcią pisarki i jej bohaterów, gdyż narratorem powieści jest mężczyzna - Harlan, trener zmagający się z własną seksualnością i miłością do swojego ucznia, otwarcie homoseksualnego i dumnego Billy'ego.

Warto w tym miejscu przywołać myśl Marka Kaplity z tekstu poświęconego koncepcji Ricoeura, że proces twórczy zawsze ukierunkowany jest na ewentualnego czytelnika i wszystkie jego etapy mają naturę dialogiczną (2013: 134). Ricoeur zauważa, że "niezależnie od tego, jak innowacyjna może być siła poetyckiej kompozycji [...] kompozycja jest zakorzeniona w przedrozumieniu świata akcji: jego rozumnych struktur, jego symbolicznych źródeł jego czasowego charakteru." (2008: 86). W wywiadzie przeprowadzonym przez Kergana Edwardsa-Stouta Warren, która sama od dzieciństwa aktywnie uprawiała sport, przyznała, że początkowo zamierzała napisać powieść o miłości między dwiema kobietami. Jednakże ze względu na powszechną w sporcie mizoginię, której sama doświadczyła, uznała, że historia zakochanych sportsmenek byłaby dla potencjalnych czytelników niewiarygodna. Chociaż jak pisze Ricoeur, "Wraz z mimesis II otwiera się królestwo j a k g d y b y” (2008: 98), decyzja o inwersji płci protagonistów i przedstawieniu doświadczenia homoseksualnych mężczyzn została odebrana przez niektóre osoby LGBTQ+ jako złamanie zasad i zawłaszczenie cudzego doświadczenia. Dominick LaCapra zauważa, że samo „pojęcie doświadczenia często okazuje się czarną skrzynką lub maksymalnie pojemnym i wszystko ogarniającym pojęciem, które pozostaje nieokreślone, ponieważ ten, kto czegoś doświadczył, zakłada, że wie, co to pojęcie oznacza" (2009: 55). Być może dlatego powieść wywołała negatywne reakcje nie tylko homoseksualnych mężczyzn, ale także lesbijek, które z kolei poczuły się zdradzone. Kwestia płci autorki „była kontrowersyjna dla bardziej poprawnych politycznie gejów, którzy uważali, że nie powinnam była pisać o mężczyznach, i powiedzieli mi o tym. Kilka razy geje i lesbijki napluli mi w twarz", wyznała Warren w wywiadzie dla Cyda Zeiglera, Jr. (2002). Co ciekawe, nie brakowało głosów, że Patricia Nell Warren to drag queen lub pseudonim mężczyzny prowadzącego tożsamościową grę z czytelnikiem (Edwards-Stout, 2013).

\footnotetext{
${ }^{9}$ Warto w tym miejscu wspomnieć, że do tematyki sportu Warren wielokrotnie powracała w eseistyce, szczególnie w tekstach pisanych dla Outsports.com, następnie zebranych w tomie The Lavender Locker Room (2006).

10 Jednakże pomimo niemal natychmiastowego sukcesu komercyjnego i późniejszego wpływu kulturowego liczba publikacji naukowych na temat The Front Runner jest zaskakująco niska, prawdopodobnie ze względu na powszechne postrzeganie powieści jako części kultury masowej, a nie tak zwanej wysokiej (Steuernagel, 1986: 125).
} 
Dla współczesnego odbiorcy takie reakcje związane z płcią mogą wydać się zaskakujące, szczególnie biorąc od uwagę, że w mimesis II „toczy się los, począwszy od czasu skonfigurowanego wcześniej po czas rekonfigurowany za pośrednictwem czasu konfigurowanego" (2008: 85) ${ }^{11}$, jednak warto pamiętać, że w momencie ukazania się powieści kultura osób LGBTQ+ dopiero zdobywała widoczność. Obawa przed komercjalizacją i zawłaszczeniem doświadczenia wydaje się więc uzasadniona. Dla Warren, przedstawicielki owej mniejszości, pisanie powieści odegrało dużą rolę w procesie akceptacji własnej orientacji seksualnej. Co więcej, mówiąc zarówno o miejscu kobiet, jak i homoseksualnych mężczyzn w amerykańskim sporcie lat 60. i 70. XX wieku, należy wziąć pod uwagę politykę społecznego ostracyzmu. Konfigurując treść powieści, Warren wykorzystała swoje doświadczenie - kobiety walczącej o własne miejsce w zdominowanym przez mężczyzn sporcie i zmagającej się z rolą heteroseksualnej żony.

\section{Świat tekstu a świat czytelnika}

Wprawdzie pisząc fikcyjną historię miłosną homoseksualnych mężczyzn, Warren pozornie opowiedziała o cudzym - męskim - doświadczeniu, zmieniając płeć swych bohaterów, ale i tak złamała maskulinistyczny i heteronormatywny kod kulturowy. W kontekście amerykańskim, podobnie jak w wielu innych tradycjach, sporty są upłciowione i odgrywają ważną rolę w kształtowaniu męskości hegemonialnej ${ }^{12}$. W związku z tym w licznych dyscyplinach grupowych kobiety i mężczyźni homoseksualni są nadal marginalizowani lub wykluczani, począwszy od edukacji wczesnoszkolnej. W swoich przełomowych tekstach poświęconych europejskiej historii sportu Norbert Elias i Eric Dunning dowodzą, że aktywność fizyczna była wykorzystywana jako narzędzie cywilizowania agresji. Autorzy zwracają uwagę, że agresywne zachowania sportowe, zgodne z określonymi wcześniej zasadami, mają na celu zaspokojenie męskiej potrzeby walki i przemocy. Według nich sporty pozwalają mężczyznom kontrolować i cywilizować przemoc.

Jak słusznie zauważa Brian Pronger, popularyzacja sportu w najnowszej historii USA wiązała się z rosnącym lękiem przed feminizacją chłopców i homoseksualizmem. Lęk ten konsekwentnie nasilał mizoginię i homofobię. Sport miał być wykorzystywany w celu potwierdzenia męskiej heteroseksualności oraz dominacji nad kobietami. Co więcej, był postrzegany jako ostatni bastion prawdziwej

\footnotetext{
${ }^{11}$ Pisząc o mimesis Riceoura, Kaplita zauważa, że zawarte w tekście „doświadczenie jest doświadczeniem ludzkim, jest doświadczeniem czyimś, ale nie stwierdzamy czyim - może ono należeć zarówno do autora, jak i czytelnika" (2013: 127).

12 Posługuję się tym terminem w rozumieniu zaproponowanym przez Raewyn Connell, opierając się na teorii hegemonii kulturowej Antonio Gramsciego, w wydanej w roku 1987 książce Gender and Power, Connell wprowadziła pojęcie męskości hegemonialnej, modelu dominującego w męskim sposobie bycia opartego na patriarchalnej nierówności płci. Idealny mężczyzna hegemonialny jest m.in. heteroseksualny, nastawiony na rywalizację, powściągliwy w okazywaniu uczuć i agresywny (Connell, 1987: 183). W wydanym prawie dwie dekady później artykule Hegemonic Masculinity: Rethinking the Concept, który powstał we współpracy z J.W. Messerchmidtem, Connell podkreśla, że na hegemonię męskości wpływ mają takie czynniki jak natura hierarchii płciowej, geografia, obraz społeczny i dynamika ról płciowych (Connell \& Messerchmidt, 2005: 847). W książce Masculinities (1995) socjolożka zaproponowała, by mówić o wielu formach męskości, oprócz hegemonialnej wymienia męskość wspótwinna, męskość podporządkowanq i męskość marginalizowaną. Badaczka zwraca uwagę, że klasyfikacja ta ma charakter płynny i zależy od wielu czynników (takich jak kultura, klasa czy rasa). Connell zauważa jednak, że wszyscy mężczyźni, nawet ci marginalizowani, czerpią korzyści z patriarchatu, co nazywa "dywidendą patriarchalną" (Connell, 1995: 41).
} 
męskości, pozwalający mężczyznom okazać dominację opartą na przemocy i sile fizycznej nad słabszymi mężczyznami (Messner, 1982: 2002). Jak twierdzi australijska badaczka Raewyn Connell, męska obsesja na punkcie sportu stała się symbolicznym dowodem ich poczucia wyższości i prawa do kontroli (1995). Jednakże kontrola ta nie mogłaby istnieć, gdyby kobiety (formalnie) i homoseksualiści (kulturowo) nie byli wykluczeni z uczestnictwa w stereotypowo hipermęskich sportach. Mimo to, jak przekonuje Pronger, „nie wszyscy homoseksualni mężczyźni i chłopcy unikają lekkoatletyki z powodu jej męskiego znaczenia," ponieważ uprawianie męskiego sportu pozwala im ukrywać swoją seksual.ność, a także rozwijać homoseksualne pragnienie w homospołecznym środowisku bez obawy o posądzenie o nieheteroseksualność (1990: 4). Jednakże, jak słusznie zauważa Eve Kosofsky Sedgwick, „homofobia jest dla patriarchatu strukturalnie niezbędna” (2005: 179), a w każdym społeczeństwie zdominowanym przez mężczyzn zachodzi szczególny związek między męskim pragnieniem homospołecznym (włącznie z homoseksualnym) a strukturami podtrzymywania i transmisji patriarchalnej władzy: "związek ugruntowany w koniecznej i potencjalnie aktywnej strukturalnej równoważności." (2005: 185). Eric Anderson, dla którego powieść Warren miała szczególne znaczenie w procesie akceptacji własnej seksualności (2005: xi), obserwuje zmieniające się nastawienie do związku między heteroseksualnością a sportem, i pokazuje bardziej inkluzywny charakter zarówno sportu, jak i amerykańskiej męskości dominującej wśród przedstawicieli młodszego pokolenia.

W The Front Runner Warren przedstawia stereotypowo męskich, wysportowanych, lecz homoseksualnych mężczyzn, którzy nie wpasowują się w konwencje z połowy ubiegłego stulecia. Jak stwierdza Harlan, przed coming outem sam borykał się z jednowymiarowym obrazem gejów: „tancerze baletowi, dekoratorzy wnętrz i aktorzy. Byli zniewieściali, ładni, trzepotali rękami, śmiesznie się poruszali i rozmawiali wysokimi, kobiecymi głosami" (Warren, 1996: 17). Dopiero gdy bohater zaczyna akceptować własną seksualność, uświadamia sobie, że "sport ma w sobie tyle homoseksualności, co inne aspekty amerykańskiego społeczeństwa - być może jeszcze więcej," gdyż "homoseksualizm to wielki trup wypadający z szafy amerykańskiej atletyki" (1996: 18). Zarówno Harlan, jak i Billy i jego koledzy Vince Matti i Jacques LaFont są stereotypowo męscy - wysportowani i silni fizycznie - co nie zmienia faktu, że po ujawnieniu się i tak muszą mierzyć się z homofobią. Warto w tym miejscu zauważyć, że chociaż większość gejów w powieści to mężczyźni hipermęscy, Warren nie unika przedstawiania innych rodzajów cis i trans męskości. Jednakże jej protagonista na kartach całej powieści mierzy się nie tylko z zewnętrzną, ale także z wewnętrzną homofobią, jak również własną transfobią i mizoginią, manifestującymi się w jego stosunku do kobiet i mężczyzn nie pasujących do modelu wysportowanej męskości.

Protagonista i jego uczniowie reprezentują też dwa różne pokolenia i przeciwstawne wizje coming outu (Steuernagel, 1986: 125-127). Chociaż zarówno dla Harlana jak i Billy'ego, Vince'a i Jacquesa ujawnienie homoseksualnej orientacji wiązało się z wykluczeniem ze społeczności akademickiej chłopców wyrzucono z prestiżowej drużyny w University of Oregon, Harlan stracił pracę trenera w Pennsylvania State University, ich dalsze doświadczenia bardzo się różnią. Dzięki znajomościom ojca Billy trafia do Harlana i wraz z kolegami prosi go o możliwość dołączenia do zespołu. Mimo że obecnie mężczyzna pracuje w Prescott, małej prywatnej szkole, której istnienie wydawało się utopijnym 
pomysłem, kiedy powieść została po raz pierwszy opublikowana, gdyż jej założyciel „zdecydował, że to, czego my [Stany Zjednoczone] potrzebujemy, to większej liczby humanitarnych ludzi, lepiej przystosowanych do przetrwania i tańszej, bardziej praktycznej edukacji" (Warren, 1974: 8), zaraz po ujawnieniu Harlan musi zmierzyć się z licznymi przeciwieństwami losu. Jednak w Prescott orientacja seksualna trenera, jak również jego wcześniejsze doświadczenia nie stanowią problemu. Dla trzech młodych biegaczy miejsce to okazuje się azylem, chociaż warto podkreślić, że trafiają do niego zaraz po wyrzuceniu z poprzedniej szkoły.

Pierwszoosobowa narracja Harlana pozwala czytelnikom głębiej poznać różnice pokoleniowe między trenerem i jego młodszym uczniem, w którym wkrótce się zakochuje. Nie licząc równie wysportowanej sylwetki i pasji do sportu, Billy w niczym nie przypomina Harlana. Jest młodym, pełnym życia wyoutowanym gejem, dla którego seksualność stanowi tylko jedną warstwę grubego palimpsestu tożsamości. Billy jest wegetarianinem, fascynuje się buddyzmem i wydaje się być w pełnej zgodzie z samym sobą. Z kolei Harlan pochodzi z tradycyjnej, chrześcijańskiej rodziny, a jego silny ojciec "nauczył [go] wielbienia na ołtarzu męskości" (Warren, 1974: 13), uprawiania sportu i nienawiści do homoseksualistów, "chorych, pokręconych ludzi" których "Pan rzuci w wieczny ogień" (1974: 19). Stopniowo trener przybliża czytelnikom własne doświadczenie coming outu i długi proces akceptacji swojej seksualności. Rodzące się uczucie do Billy'ego prowokuje Harlana do symbolicznej podróży do krainy dzieciństwa i młodości, i zmierzenia się z traumatycznymi doświadczeniami. Mężczyzna wspomina pierwsze zauroczenie chłopakiem, Chrisem Shelbournem, którego poznał na obozie i towarzyszącą mu wtedy świadomość, że „te uczucia powinny być ukryte przed wszystkimi, nawet przed Chrisem, nawet przed samym sobą" (1974: 14). Następnie narrator przywołuje wieloletnie zmagania z własną homoseksualnością, próby jej zaprzeczania poprzez uprawianie sportu, zostanie żołnierzem Korpusu Piechoty Morskiej Stanów Zjednoczonych i wreszcie podrywanie dziewczyn i uprawianie z nimi seksu (często myśląc o Chrisie i innych mężczyznach). Zwieńczeniem procesu wyparcia jest ciąża jednej z przelotnych partnerek i spowodowany nią ślub.

Związek z Mary Ellen Rache nie rozwiązał problemu Harlana. Posiadanie żony i dwóch synów nie zniwelowało nieustannych rozterek wewnętrznych. Dopiero podróże służbowe do Nowego Jorku pozwoliły bohaterowi stopniowo, ukradkiem zgłębić swoje homoseksualne pragnienia i zacząć rozumieć wewnętrzną i zewnętrzną homofobię. "W te” - jak wspomina - "niebezpieczne weekendy. Zawsze czułem się jak szpieg przebywający za żelazną kurtyną w środku jakiejś niepokojącej misji” (Warren, 1974: 26). To wtedy Harlan po raz pierwszy zaczął dostrzegać społeczną wiktymizację homoseksualistów:

Wkrótce poczułem to oszołomienie, tę dławiącą wściekłość, że na gejów poluje się jak na zwierzęta. Tłoczyliśmy się w ciemnościach pod ziemią, jak chrześcijanie w katakumbach, chroniąc maleńki płomień naszej seksualnej wiary. Czy cesarz ogłosi edykt, który wypuściłby nas na światło? Jaką szkodę zrobiliśmy? Mordercy i złodzieje skrzywdzili innych, ale my nie wyrządziliśmy krzywdy nikomu, oprócz [...] nas samych. (1974: 26-27) 
Co więcej, po raz pierwszy Harlan zaczyna też identyfikować się jako członek społeczności gejowskiej, ponieważ, pomimo swoich seksualnych doświadczeń, wcześniej stereotypowo i homofobicznie pojmował środowisko osób nieheteronormatywnych. Gdy wreszcie zostaje zmuszony do ujawnienia swojej homoseksualności, traci pracę, rozwodzi się, a ze względu na konieczność płacenia wysokich alimentów zostaje pracownikiem seksualnym i wchodzi w nowojorski półświatek. Jednakże, jak słusznie zauważa Steuernagel, praca ta nie degraduje Harlana, nie sprawia, że staje się wyrzutkiem, ale symbolicznie zmienia go w wojownika (1986: 25-127). Jak stwierdza sam bohater: „Było coś w surowości zgiełku, co przypominało mi, że przeżyłem, że ulica mnie nie zmiażdży" (Warren, 1974: 32-33). Dołączenie do nowojorskiej społeczności gejów umożliwia mu bezpośrednie uczestnictwo w zamieszkach w Stonewall, wydarzenie to wspomina jako ważne i wzmacniające w procesie samoakceptacji.

Ten trudny proces coming outu znacznie różni się od tego, przez który przeszedł Billy, wychowany przez homoseksualnego ojca, adwokata i działacza społecznego zajmującego się prawami obywatelskimi osób nieheteronormatywnych i jego transseksualną partnerkę. Harlan reprezentuje amerykańską homofobię i mizoginię, typową dla swojego pokolenia. Po pierwsze, nie lubi zniewieściałych mężczyzn. Po drugie, co wydaje się szczególnie ciekawe w utworze napisanym przez kobietę, wielokrotnie dyskryminuje heteroseksualne kobiety. Żonę sprowadza wyłącznie do roli problemu (dziecko, ślub, nieszczęśliwy heteronormatywny związek zbudowany na kłamstwie, brak satysfakcji, zdrady, utrata kariery, rozwód, alimenty, ograniczenie relacji z synami). Kobieta zostaje uprzedmiotowiona, oszukana i odrzucona, a następnie potraktowana jako bezpośrednia przyczyna tego, że jej były mąż został męską prostytutka. Również matki Harlana i Billy'ego przedstawione są negatywnie, gdyż nie mogą zaakceptować swoich synów. Chociaż Billy wydaje się reagować dość spokojnie, gdy jego biologiczna matka mówi: „Bóg ukarze was obu” (Warren, 1974: 213), Harlan jest wściekły, gdyż, kobieta przypomina mu jego własne doświadczenia z rodzicami. Jedyne pozytywne postaci matek w powieści to kobiety nieheteronormatywne: transseksualna macocha Billy'ego i Betsy, lesbijka i matka dziecka Billy'ego i Harlana. Jednakże nawet z Betsy protagonista nie ma dobrego kontaktu, a z wydanej w 1997 roku kontynuacji Billy's Boy dowiadujemy się, że po śmierci Billy'ego ich stosunki ulegają znacznemu pogorszeniu.

Co ciekawe, powieść jednocześnie promuje heteronormatywny w swej genezie model monogamicznej relacji gejowskiej. Harlan i Billy stawiają czoło przeciwnościom losu i biorą symboliczny ślub (małżeństwo jest prawnie nieważne), pragną też mieć dziecko. Chociaż narracja zmierza ku szczęśliwemu zakończeniu - Billy zostaje ikoną amerykańskich gejów i zdobywa medal olimpijski na igrzyskach w Montrealu w 1976 roku - zostaje jednak zabity przez homofoba podczas biegu po drugi medal. Finał ten poniekąd nie zaskakuje - szczególnie czytelników znających późniejsze powieści LGBTQ+, w których motyw samobójstwa lub homofobicznego morderstwa jest częsty. Tragiczna śmierć Billy'ego powoduje dalszą heteronormizację - Harlan wraz z Betsy postanawiają wykorzystać zamrożone nasienie Billy'ego i pod koniec powieści kobieta rodzi jego biologiczne dziecko, które Harlan postanawia 
wychować ${ }^{13}$. Mężczyzna traktuje dziecko Billy'ego jako owoc wielkiej miłości, w przeciwieństwie do swoich biologicznych dzieci z poprzedniego małżeństwa, z którymi nie ma żadnego kontaktu. Ten ciekawy zabieg pozwolił Warren powrócić do Harlana i jego syna w powieściach Harlan's Race i Billy's Boy, w których autorka odnosi się do innych aspektów homofobii i sytuacji osób nie heteronormatywnych w latach 80. i 90. XX wieku.

\section{Konkluzja}

Chociaż obecnie amerykańskie książki o tematyce gejowskiej, takie jak choćby popularne w ostatnich latach Call Me by Your Name André Acimana (2007) i Simon vs. Homo Sapiens Becky Albertalli (2015), są bestsellerami i doczekały się już hollywoodzkich ekranizacji, na przełomie lat 60. i 70. XX wieku wydawcy wciąż wahali się, czy promować ten rodzaj literatury, nawet po zamieszkach w Stonewall. Kiedy The Front Runner ukazał się w 1974 roku, otworzył drzwi kolejnym pokoleniom popularnej prozy o tematyce gejowskiej, również tej o dyskusyjnej jakości. O istotności powieści świadczy choćby fakt, że w czerwcu 2019 roku Warren znalazła się wśród osób, których nazwisko zagościło na National LGBTQ Wall of Honor, pierwszym tego typu miejscu pamięci w USA, odsłonionym przy okazji obchodów pięćdziesięciolecia zamieszek w legendarnym Stonewall Inn. Współczesnym młodym czytelnikom kwestia negatywnego odbioru The Front Runner może wydać się niezrozumiała, gdyż amerykańscy pisarze, choćby autorzy wspomnianych wyżej bestsellerów, nie musieli mierzyć się z podobną krytyką (Becky Albertalli jest kobietą a André Aciman heteroseksualnym mężczyzną). Co więcej, sam odbiór The Front Runner wśród młodszych pokoleń czytelników może znacząco się różnić, szczególnie przez warstwę językową, tradycyjną formę, jak również obecną w utworze mizoginię i heteronormatywność oraz kliszową romantyzację związku dwóch mężczyzn. Jednakże chciałbym zauważyć, że wartość poznawcza The Front Runner jest nieoceniona, gdyż powieść jest bodaj najlepszą literacką reprezentacją zmieniającej się sytuacji społecznej osób nieheteroseksualnych w USA w latach 60 . i pierwszej połowie lat 70. Zawiera też potencjalną wartość rozbudzania empatii i może stanowić medium pamięci protetycznej również dla europejskich czytelników, gdyż, jak zauważa Landsberg, kultura i literatura popularna mogą wpływać na kulturę pamięci, pozwalając przejąć obce, nawet odległe kulturowo doświadczenie i wspomnienia obcych ludzi i wspólnot "niczym sztuczną kończynę"14 (2018: 165-172). W końcu jak pisze Erll, „Świat pamięci kulturowej jest światem narracji” (2018: 229), a literatura tworzy kulturę pamięci nie tylko poprzez treści, ale także formę i strukturę.

Powracając do przywołanej wcześniej koncepcji potrójnej mimesis pragnę podkreślić, że proces wymiany między doświadczeniem autora i czytelnika a opowieścią ma w niej charakter dynamiczny

\footnotetext{
${ }^{13}$ W Billy's Boy dowiadujemy się jednak, że ze względu na homofobię dziecko samotnie wychowuje Betsy. O istnieniu Harlana (któremu Betsy co roku wysyła zdjęcia dziecka) i Billy'ego tytułowy bohater dowiaduje się, dopiero będąc nastolatkiem, gdy mierzy się z własną biseksualnością. Co więcej, w tym samym utworze okazuje się, że biologicznym ojcem Williama jest Harlan. O powieści piszę z Justyną Mętrak w artykule "Growing Up and Memory of the Margins in Patricia Nell Warren's (Patricia Kilina's) Billy's Boy" TEKA Komisji Polsko-Ukraińskich Związków Kulturowych 2019 (vol. 14, 2019: 169-184).

${ }^{14}$ Więcej na temat relacji pamięci, mediów i literatury zob: Erll, 2018: 182-263.
} 
i "wprawia koło mimesis w ruch” (Ricoeur, 2008: 126). Powieść Warren okazała się przełomem w karierze autorki i w życiu wielu amerykańskich czytelników. Biorąc pod uwagę zarówno trudny rozwój kultury i literatury LGBTQ + na Ukrainie, jak i wciąż powszechną u naszych wschodnich sąsiadów homofobię (Chernetsky, 2016: 206-225), szkoda, że wciąż nie ukazał się przekład The Front Runner na język ukraiński i rosyjski. Warto zauważyć, że Warren była jedyną żyjąca w roku 2017 członkinią Grupy Nowojorskiej, która nie wystąpiła w poświęconym fenomenowi tego ugrupowania filmie dokumentalnym An Aquarium in the Sea. The Story of New York Group Oleksandra Fraze-Frazenko. Wypowiadając się o autorce The Fancy Dancer Bohdan Boychuk i Bohdan Rubchak mizoginicznie podkreślają, że była piękną i seksowną kobietą, w której wszyscy mężczyźni się kochali, natomiast jej relację z mężem określają jako od początku trudną i dysfunkcyjną. Tarnawski według ich słów był nie tylko agresywny i apodyktyczny w stosunku do żony, ale również deprecjonował jej dokonania i zazdrościł pozytywnego odbioru pierwszego, surrealistycznego zbioru poezji, szczególnie po nieprzychylnych recenzjach własnych utworów. Na pytanie o pierwszą żonę sam pisarz odmawia odpowiedzi. Chociaż orientacja seksualna Kiliny/Warren jest w filmie pokrótce wspomniana, potraktowano ją jako kwestię wstydliwą i niezrozumiałą. Co istotne w kontekście niniejszego tekstu, Boychuk wspomina wydanie The Front Runner i porównuje relację Warren i Tarnawskiego do tej Harlana i Billy'ego, stwierdzając, że dzięki mężowi/trenerowi autorka zapisała się na kartach historii literatury ukraińskiej. Chociaż Patricia Nell Warren dokonała coming outu i odzyskała własną tożsamość w roku 1973, Patricia Kilina wciąż w niej symbolicznie tkwi i funkcjonuje w ukraińskim dyskursie literackim jako pierwsza, tajemnicza żona Tarnawskiego, która karierę zakończyła na początku lat 70 . Niestety jej ukraińskojęzyczne utwory nadal nie doczekały się należytego opracowania - mimo ich niezaprzeczalnej wartości artystycznej, o której w filmie Fraze-Frazenko mówią choćby Jurij Andruchowycz i Maria Rewakowicz - a anglojęzyczna, gejowska twórczość wciąż pozostaje w naszym regionie nieznana.

\section{Bibiliografia}

Anderson, Erik (2005), In the Game: Gay Athletes and the Cult of Masculinity, Albany, State University of New York Press.

Assmann, Aleida (2018), Między historią a pamięcią: antologia, Warszawa, Wydawnictwo Uniwersytetu Warszawskiego.

Chernetsky, Vitaly (2016), „Ukrainian Queer Culture: The Difficult Birth”, Queer Stories of Europe, Kārlis Verdiṇš i Jānis Ozoliṇ̌s (red.), Newcastle upon Tyne: Cambridge Scholars Press: 206-225.

Connell, R.W. (Raewyn) (1987), Gender and Power, Sydney, Allen and Unwin.

Connell, R.W. (Raewyn) (1995), Masculinities, Cambridge, Polity Press.

Connell R.W. (Raewyn) i James W. Messerchmidt (2005), „Hegemonic Masculinity: Rethinking the Concept", Gender \& Society, 19.6: 829-859, https://doi.org/10.1177/0891243205278639

Dunning, Eric (1999), Sport Matters: Sociological Studies of Sport, Violence and Civilization, London, Routledge. 
Edwards-Stout, Kergan (2013), "Legendary Author Patricia Nell Warren: Ever the Front Runner", Huffington Post, 16.01.2013, https://www.huffingtonpost.com/kergan-edwardsstout/patricianell-warren_b_2452879.html

Elias Norbert i Eric Dunning (1986), Quest for Excitement. Sport and Leisure in the Civilizing Process, Oxford, Basil Blackwell.

Erll Astrid (2018), Kultura pamięci: wprowadzenie, Warszawa, Wydawnictwo Uniwersytetu Warszawskiego, https://doi.org/10.31338/uw.9788323534174

Frazé-Frazénko, Oleksandr (2017), „An Aquarium in the Sea. The Story of New York Group (An Oleksandr Fraze-Frazenko film)", YouTube, https://www.youtube.com/watch?v=GBlvb3NM5eM

Kaplita, Marek (2013), „Autor, dzieło i czytelnik w świetle potrójnej mimesis Paula Ricoeura”, Estetyka i Krytyka, 2.29: 115-137.

Kosofsky Sedgwick, Eve (2005), „Męskie pragnienie homospołeczne i polityka seksualności”, przeł. Adam Ostolski, Krytyka Polityczna, 9/10: 176-177.

LaCapra, Dominick (2009), Historia w okresie przejściowym. Doświadczenie, tożsamość, teoria krytyczna, przeł. Katarzyna Bojarska, Kraków, Universitas: 50-95.

Landsberg, Alison (2018), „Ameryka, Holokaust i masowa kultura pamięci. W stronę radykalnej polityki empatii", przeł. Paweł Dobrosielski, Antropologia pamięci: zagadnienia i wybór tekstów, Paweł Majewski i Marcin Napiórkowski (red.), Warszawa, Wydawnictwo Uniwersytetu Warszawskiego: 165-172, https://doi.org/10.31338/uw.9788323533627.pp.165-172

Messner, Michael (1982), Power at Play: Sports and the Problem of Masculinity, Boston: Beacon Press.

(2002), Taking the Field: Women, Men, and Sports, Minneapolis, University of Minnesota Press.

Masenko, Łarysa (2008), Język i społeczeństwo: Wymiar postkolonialny, przeł. Artur Bracki, Gdańsk, Wydawnictwo Uniwersytetu Gdańskiego.

Pew Research Center (2018), „Eastern and Western Europeans Differ on Importance of Religion, Views of Minorities, and Key Social Issues", http://www.pewforum.org/2018/10/29/easternand-western-europeans-differ-on-importance-of-religion-views-of-minorities-and-key-socialissues/?fbclid = IwAR0zNjRTbH3y2lkralxFGnR9Xtfn2mJTzVzu0AHftJ6aexsbFYO6yioVqpo

Pronger, Brian (1990), The Arena of Masculinity: Sports, Homosexuality, and the Meaning of Sex, New York, St. Martin's Griffin.

Revakovič Mariâ (2005), Pivstolittâ napivtiši: Antologiâ poezï̈ N'û-Jorks'koï grupi, Kiiv, Fakt.

Ricoeur, Paul (2008), Czas i opowieść, t. 1, Intryga i historyczna opowieść, przeł. Małgorzata Frankiewicz, Kraków, Eidos.

Simon, Scott (2008), "Author Examines Gay Athletes", NPR, https://www.npr.org/templates/story/story.php?storyld=93465294

Steuernagel, Trudy (1986), "Contemporary Homosexual Fiction and Gay Rights", The Journal of Popular Culture, Winter: 125-134, https://doi.org/10.1111/j.0022-3840.1986.2003_125.x 
Świetlicki, Mateusz, Justyna Mętrak. "Growing Up and Memory of the Margins in Patricia Nell Warren's (Patricia Kilina's) Billy's Boy", TEKA Komisji Polsko-Ukraińskich Zwiq̨zów Kulturowych, vol. 14 2019: 169-184.

Valocchi, Stephen (2004), "Stonewall Riots”, Men and Masculinities. A Social, Cultural, and Historical Encyclopedia, Amy Aronson i Michael S. Kimmel, Santa Barbara, ABC-CLIO: 760-762.

Warren, Patricia Nell (1996), The Front Runner, Beverly Hills, Wildcat [wydanie pierwsze: Warren, P.N. (1974), The Front Runner, New York, Bantam Books].

- (2014), "Tragedia pszczół - będąc poetką na wygnaniu”, przeł. Mateusz Świetlicki, W: Miscellanea Posttotalitariana Wratislaviensia, 2: 317-327.

Zeigler, Cyd Jr. (2002), "Still A Front Runner", Outsports, https://web.archive.org/web/20110907004316/http:/www.outsports.com/difference/pnw.htm 